\title{
Clinical-pathological review of 14 cases of merkel cell carcinoma
}

Adel Quttainah MD ${ }^{1}$, Achilles Thoma MD FRCSC FACS ${ }^{1}$, Samih Salama MB FRCPC ${ }^{2}$

A Quttainah, A Thoma, S Salama. Clinical-pathological review of 14 cases of merkel cell carcinoma. Can J Plast Surg 2002;10(5):196-202.

Merkel cell carcinoma (MCC) is a rare, primary, cutaneous, neuroendocrine skin tumour that occurs commonly in the head, neck or extremities of elderly white people. Fourteen cases of MCC in the Hamilton Regional Cancer Centre between 1992 and 2000 have been reviewed. Seven cases required a panel of immunohistochemical markers and two cases required electron microscopy for confirmation. Seven men and seven women were treated, and ranged from 67 to 96 years of age (mean 77.7 years). The primary tumour was located in the head and neck in seven patients $(50 \%)$, in the extremities in four patients (29\%) and on the trunk in two patients $(14 \%)$. One patient had an unknown primary tumour location. Ten patients had stage Ia disease at presentation, three had stage Ib disease, and one presented with stage II disease. Primary treatment consisted of wide local excision in nine patients, wide local excision and radiotherapy in four patients and radiotherapy only in one patient. Seven patients had recurrence, five were disease free up to their most recent followup, one died of unrelated causes, and one was lost to follow-up after primary treatment. Of the seven patients with recurrence, two had local recurrence, two had lymph node recurrence and three developed metastases. Disease-free intervals were 69\% and $50 \%$ for six-month and one-year follow-up, respectively. No difference in outcome was observed between stage Ia and Ib disease. The patient with stage II disease at presentation developed metastases. Longer duration of disease before presentation had a higher incidence of recurrence with distant metastases. Extremity lesions had the best prognosis associated with disease-free interval. Early management with excision and radiotherapy improved the disease-free interval.

Key Words: Merkel cell carcinoma; Neuroendocrine tumour, Trabecular cell carcinoma

Résumé à la page suivante

This paper was presented at the Canadian Society of Plastic Surgeons Annual Meeting, Jasper, Alberta, June 2001

${ }^{1}$ Department of Surgery, Division of Plastic and Reconstructive Surgery; ${ }^{2}$ Department of Pathology, St Joseph's Healthcare and McMaster University, Hamilton, Ontario

Correspondence and reprints: Dr Achilles Thoma, 206 James Street South, Suite 101, Hamilton, Ontario L8P 3A9. Telephone 905-523-0019, fax 905-523-0229, e-mail athoma@mcmaster.ca 


\section{L'azoospermie : Les évaluations et les traitements}

\begin{abstract}
RÉSUMÉ : L'azoospermie peut être causée par l'obstruction du système canalaire excrétoire des voies reproductrices mâles ou par l'échec de la spermatogenèse des testicules. Il existe divers outils diagnostiques avancés pour aider les cliniciens à déterminer les étiologies sous-jacentes. Ces outils incluent l'échographie transrectale, la vasographie et le dosage des anticorps immobilisants. De plus, des évaluations génétiques évoluées, telles que le caryotypage, la microdélétion du chromosome Y et le dépistage de la mutation du régulateur de la conductance membranaire de la fibrose kystique sont souvent utilisées, non seulement pour établir
\end{abstract}

l'étiologie de l'azoospermie, mais également pour fournir de l'information essentielle en vue de conseiller les couples qui choisissent de faire appel aux techniques de reproduction assistée pour avoir des enfants. Les récents progrès dans la prise en charge de l'azoospermie obstructive par la reconstruction microchirurgicale, comme la vasovasostomie et la vasoépididymostomie, ont amélioré considérablement les issues postopératoires. Dans le cas des patients présentant un échec spermatogène et qui ont besoin de reproduction assistée, les raffinements récents des diverses techniques chirurgicales d'extraction du sperme, y compris l'extraction microchirurgicale du sperme testiculaire et l'aspiration du sperme épipidymal, assurent des issues plus optimales des traitements.
$\mathrm{M}$ erkel (1) described the cell that carries his name in 1875. Merkel cells are neuroendocrine cells that reside within the basal layer of the epidermis (2).

They form complexes with terminal axons to act as mechanoreceptors to pressure. Merkel cell carcinoma (MCC), or trabecular cell carcinoma, was first reported by Toker in 1972 (2). He originally described the Merkel cell tumour as a trabecular carcinoma, because he thought the sweat glands were the tissue of origin. In 1978, Tang and Toker (3) found the tissues of origin to be Merkel cells.

MCC is a primary cutaneous neuroendocrine carcinoma occurring most commonly in elderly white people, with equal distribution between men and women. Fewer than 2000 cases have been reported to date (4). It is an aggressive tumour that occurs most frequently in the head and neck region, followed by the extremities and trunk (5). The tumour presents clinically as a rapidly growing, firm, cutaneous, nontender nodule with red or bluish colour, measuring up to several centimetres (6). It typically increases rapidly in size over a few weeks to months and rarely ulcerates (7). MCC has a local recurrence rate of $28.9 \%$ after primary treatment, a $51.9 \%$ rate of lymph node metastases and a $35.2 \%$ rate of distant metastases (8). The three-year survival rates are reported to be $36 \%$ for men and $68 \%$ for women $(4,8)$.

The diagnosis of MCC is often not made before biopsy. Differential diagnosis includes squamous cell carcinoma, basal cell carcinoma, malignant melanoma and adnexal tumours. Pathological and histological differential diagnosis includes metastatic small cell carcinoma, lymphoma and leukemia (9). This can be confirmed by immunohistochemistry and electron microscopy. The immunohistochemical expression of specific patterns of cytokeratin and other intermediate filaments by an undifferentiated dermal tumour helps in the diagnosis of MCC and in differentiating it from small cell carcinoma of the lung (8).

As demonstrated by Chan et al (10), positivity for cytokeratin in a small cell carcinoma of uncertain origin is a strong predictor of MCC. The predisposing factors leading to the evolution of MCC are unknown. Sun exposure may be a factor because the tumour is usually localized in sun exposed areas of the head and neck; however, it can occur in areas that are not exposed to the sun, such as the extrem- ities, trunk or genitalia. There also appears to be increased prevalence in regions with a high incidence of skin cancer $(11,12)$. In addition, patient populations have shown a history of basal cell cancer, Bowen's disease or squamous cell cancer of the skin, and other coexisting skin diseases such as psoriasis, which may render an area susceptible to the development of a cutaneous Merkel cell tumour (13). Immunosuppression has also been associated with MCC. The purpose of the present paper is to review our experience in the Hamilton, Ontario region and to compare it with the experiences in the literature.

\section{MATERIALS AND METHODS}

Fourteen cases of MCC were identified at the Hamilton Regional Cancer Centre registry from December 1992 to July 2000.

Pathologically, the light microscopic diagnosis of MCC was confirmed by immunohistochemistry in seven cases and by electron microscopy in two cases.

\section{Light microscopy}

The tissue was fixed in 10\% neutral buffered formalin and processed routinely in paraffin blocks. Five micrometre sections were stained with hematoxylin and eosin, and were examined under light microscopy.

\section{Immunohistochemistry}

Two to four micrometre sections of formalin-fixed paraffinembedded tissue were stained with the primary antibodies listed in Table 1 (Dako Diagnostics, Canada), using the labelled streptavidin biotin method.

\section{Electron microscopy}

Representative tumour tissue was cut into approximately $1 \mathrm{~mm}^{3}$ portions, fixed in $2 \%$ glutaraldehyde in $0.1 \%$ sodium cacodylate buffer, and were postfixed in $1 \%$ osmium oxide and Spurr's resin. Thin sections were then cut and stained with uranyl acetate and lead citrate. Examination and photography were undertaken by a Philip 300 microscope (Philip Harris, Holland).

\section{Management}

In addition to the physical examination, chest $\mathrm{x}$-rays and 
TABLE 1

Immunohistochemistry results

\begin{tabular}{lccccccc}
\hline Case & 2 & 4 & 5 & 7 & 9 & 11 & 12 \\
\hline Pankeratin & & + & & & + & & + \\
$\begin{array}{l}\text { Low molecular } \\
\text { weight keratin }\end{array}$ & + & + & + & + & + & & +
\end{tabular}

High molecular

weight keratin

AE1/AE3 keratin

Cytokeratin 20

Epithelial

membrane antigen ++

Carcinoembryonic

antigen

Leukocyte

common antigen

$\mathrm{S} 100$

Melanoma-specific antigen

Chromogranin

Synaptophysin

Neuron-specific enolase

CD57

Neurofilament

Protein gene

product 9.5

Ber-EP4

Vimentin

C-Kit

Calcitonin

+ Positive reaction with antibody; - Negative reaction with antibody

blood work were performed. Treatment modalities included excision only, primary radiotherapy with surgical excision, radiation only, radiotherapy of local or regional lymph nodes, lymph node dissection, and treatment of recurrences. Response to therapy and final disease status at the time of review were also assessed. The outcome between primary surgical excision only and primary surgical excision and radiotherapy was analyzed statistically.
Patients were staged according to the absence of positive regional lymph node involvement (stage I), and further subdivided to tumour size of $2 \mathrm{~cm}$ or less (stage Ia) and tumour size of more than $2 \mathrm{~cm}$ (stage $\mathrm{Ib}$ ). If there was involvement of regional lymph nodes, tumours were considered to be stage II, and if there was a presence of distant metastases, tumours were considered to be stage III.

\section{RESULTS}

\section{Patient characteristics}

Seven men and seven women with MCC were reviewed (Table 2). The primary tumour was located in the head and neck region of seven patients $(50 \%)$, in the extremities of four patients $(29 \%)$ and on the trunk in two patients (14\%). One patient had an unknown primary tumour location and was in stage II at presentation, with nodal involvement $(7 \%)$. The mean age at the time of diagnosis was 77.7 years (range 67 to 96 years).

\section{Pathology}

The lesions ranged from 0.7 to $2.5 \mathrm{~cm}$ in diameter (Figure 1). The tumours were located within the dermis, and some infiltrated the adjoining fat or muscle but were separated from the overlying epidermis by uninvolved collagen (Figure 2). The tumour cells were arranged in sheets, trabeculae and, less commonly, ribbons, and the neoplastic cells were generally small and had scanty cytoplasm and dense nuclear chromatin (Figure 3). The results of the immunohistochemical findings are listed in Table 1 . The keratin markers showed characteristic perinuclear dot-like staining corresponding to the intermediate filaments (Figure 4). Ultrastructurally, cytoplasmic membranebound, round, dense, core 'neuroendocrine' granules measuring 110 to $140 \mathrm{~nm}$ in diameter were seen (Figure 5). Perinuclear aggregates, or bundles of intermediate filaments measuring 7 to $10 \mathrm{~nm}$ wide, were also seen, as were small, dermosomal, intercellular junctions.

\section{Clinical course and outcome}

At initial presentation, stage Ia disease was present in 10 patients $(71.4 \%)$, involving six in the head and neck region, two in the extremities and two in the trunk. Stage Ib disease was present in three patients (21.4\%), two involved the extremities and one involved the head and neck region. One patient $(7.14 \%)$ presented with stage II disease. The mean duration of disease before presentation was 7.04 months (range one to 36 months).

After initial excisional or incisional biopsy, wide local excisions were performed on 13 patients. One patient received radiotherapy only to the initial tumour, with no surgical excision. Nine patients had wide local excision only, and four had wide local excision with radiotherapy as the initial treatment.

When analyzing recurrence with different types of treatment, of the nine patients who received wide local excision only as the primary initial treatment, seven had recurrences within 0.5 to 16 months (mean time of 6.21 months). Of 
TABLE 2

Database of 14 patients with diagnosis of Merkel cell carcinoma in Hamilton Regional Cancer Centre, Hamilton, Ontario

\begin{tabular}{|c|c|c|c|c|c|c|c|c|c|c|c|}
\hline Case & Age & Sex & $\begin{array}{l}\text { Primary } \\
\text { tumour } \\
\text { location }\end{array}$ & Size & Stage & $\begin{array}{c}\text { Duration to } \\
\text { treatment } \\
\text { (months) }\end{array}$ & $\begin{array}{l}\text { Initial } \\
\text { treatment }\end{array}$ & $\begin{array}{l}\text { Recurrence } \\
\text { location }\end{array}$ & $\begin{array}{c}\text { Disease-free } \\
\text { interval } \\
\text { (months) }\end{array}$ & $\begin{array}{l}\text { Further } \\
\text { treatment } \\
\text { after } \\
\text { recurrence }\end{array}$ & $\begin{array}{l}\text { Status at } \\
\text { most recent } \\
\text { follow-up } \\
\text { (months) }\end{array}$ \\
\hline 1 & 72 & $M$ & Left arm & $<2 \mathrm{~cm}$ & la & 8 & $\begin{array}{l}\text { Excision } \\
\quad \text { with radiation }\end{array}$ & n & & & DF (6) \\
\hline 2 & 68 & $\mathrm{~F}$ & Right thigh & $2.5 \times 2 \mathrm{~cm}$ & $\mathrm{lb}$ & 3 & $\begin{array}{l}\text { Excision } \\
\text { with radiation }\end{array}$ & n & & & DF (36) \\
\hline 3 & 67 & $\mathrm{~F}$ & Left thigh & $2.3 \times 1.2 \mathrm{~cm}$ & $\mathrm{lb}$ & 2 & Excision only & LN & 2 & LN dissection & $\begin{array}{l}\text { DF (4), after } \\
\text { recurrence }\end{array}$ \\
\hline 4 & 85 & $\mathrm{~F}$ & Left leg & $1.4 \times 1.5 \mathrm{~cm}$ & la & 2.5 & Local radiation & - & & & DF (36) \\
\hline 5 & 73 & M & Left temp & $1.5 \mathrm{~cm}$ & la & 3.5 & Excision only & L & 0.5 & Local radiation & $\begin{array}{l}\text { Living, treat- } \\
\text { ment with } \\
\text { radiation }\end{array}$ \\
\hline 6 & 81 & $\mathrm{~F}$ & $\begin{array}{l}\text { Scalp and } \\
\text { neck }\end{array}$ & $2 \mathrm{~cm}$ & la & 1.5 & Excision only & $\begin{array}{l}\text { L,LN,Ms } \\
\text { lungs }\end{array}$ & 2.5 & Local radiation & $\begin{array}{l}\text { Palliative } \\
\text { radiation }\end{array}$ \\
\hline 7 & 89 & $\mathrm{~F}$ & $\begin{array}{l}\text { Right ala } \\
\text { of nose }\end{array}$ & $<2 \mathrm{~cm}$ & la & 3.5 & Excision only & & & $\begin{array}{l}\text { Refused further } \\
\text { treatment }\end{array}$ & $\begin{array}{l}\text { Lost to } \\
\text { follow-up }\end{array}$ \\
\hline 8 & 96 & $\mathrm{~F}$ & Left cheek & $2.1 \mathrm{~cm}$ & $\mathrm{lb}$ & 3 & Excision only & - & 7 & & $\begin{array}{l}\text { Died of other } \\
\text { causes }\end{array}$ \\
\hline 9 & 74 & M & $U$ & & II & 36 & $\begin{array}{l}\text { LN excisional } \\
\text { biopsy }\end{array}$ & Ms Liver & 5 & Radiation & $\begin{array}{l}\text { Died of MCC } \\
10 \text { months } \\
\text { after } \\
\text { treatment }\end{array}$ \\
\hline 10 & 91 & $\mathrm{~F}$ & $\begin{array}{c}\text { Left } \\
\text { forehead }\end{array}$ & $1.8 \mathrm{~cm}$ & la & 20 & Excision only & $\begin{array}{l}\text { L,LN,Ms } \\
\text { lungs }\end{array}$ & 8 & Local radiation & $\begin{array}{l}\text { Living with } \\
\text { disease, } \\
\text { palliative } \\
\text { treatment }\end{array}$ \\
\hline 11 & 74 & M & Right pinna & $7 \times 7 \mathrm{~mm}$ & la & 6 & $\begin{array}{l}\text { Excision with } \\
\text { radiation }\end{array}$ & - & & & DF (36) \\
\hline 12 & 79 & $M$ & $\begin{array}{c}\text { Left } \\
\text { forehead }\end{array}$ & $1.1 \mathrm{~cm}$ & la & $U$ & Excision only & L,LN & 14 & Local radiation & $\begin{array}{l}\text { Living with } \\
\text { disease, } \\
\text { palliative } \\
\text { treatment }\end{array}$ \\
\hline 13 & 68 & M & $\begin{array}{c}\text { Left } \\
\text { shoulder }\end{array}$ & $2 \mathrm{~cm}$ & la & 2 & $\begin{array}{l}\text { Excision with } \\
\text { radiation }\end{array}$ & - & & & DF (6) \\
\hline 14 & 81 & M & $\begin{array}{c}\text { Right } \\
\text { chest wall }\end{array}$ & $<2 \mathrm{~cm}$ & la & 1 & Excision only & L & 16 & Local radiation & $\begin{array}{c}\text { DF }(36), \text { after } \\
\text { recurrence }\end{array}$ \\
\hline
\end{tabular}

DF Disease free; F Female; L Local; LN Lymph node; M Male; Ms Metastases; MCC Merkel cell carcinoma; U Unknown

the remaining two patients who had wide local excision as the primary treatment, one patient died due to respiratory failure and one patient was lost to follow-up.
Of the four patients receiving wide local excision with radiotherapy initially, three patients had wide local excision with local radiotherapy and remained disease free up to the 


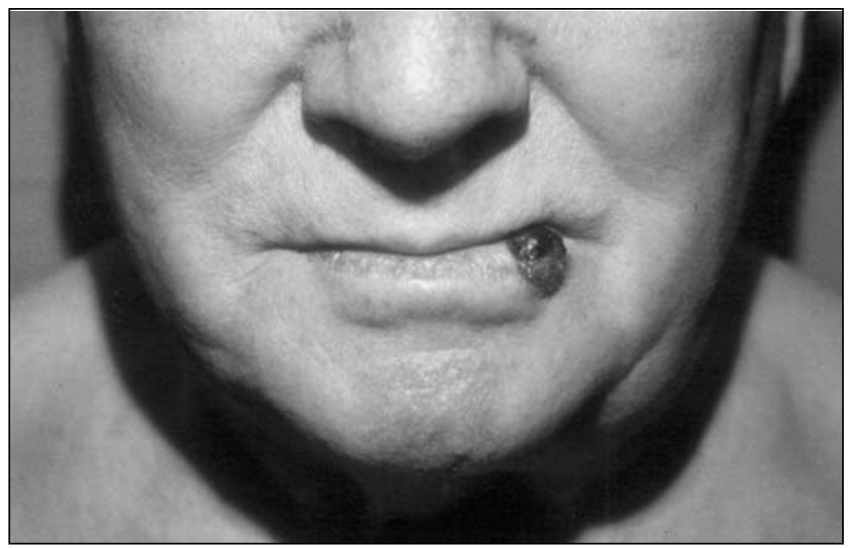

Figure 1) Gross appearance of Merkel cell tumour. Tumour nodule on skin of the lip measuring approximately $1.5 \mathrm{~cm}$ in diameter. (Note: this patient was not included in the present study)

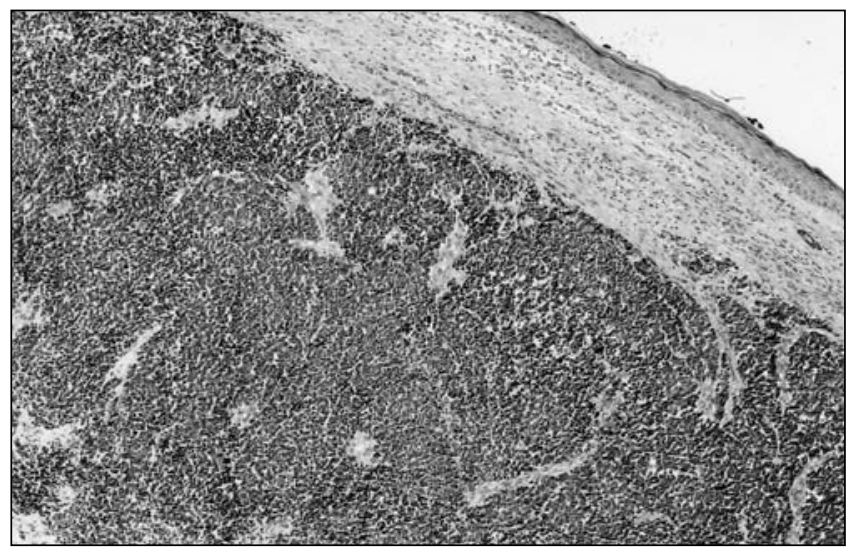

Figure 2) Low power view of Merkel cell tumour. Sheets of tumour cells separated from the overlying epithelium by zone of uninvolved collagen. Unremarkable epidermis (hematoxylin and eosin stain, original magnification $\times 25$ ).

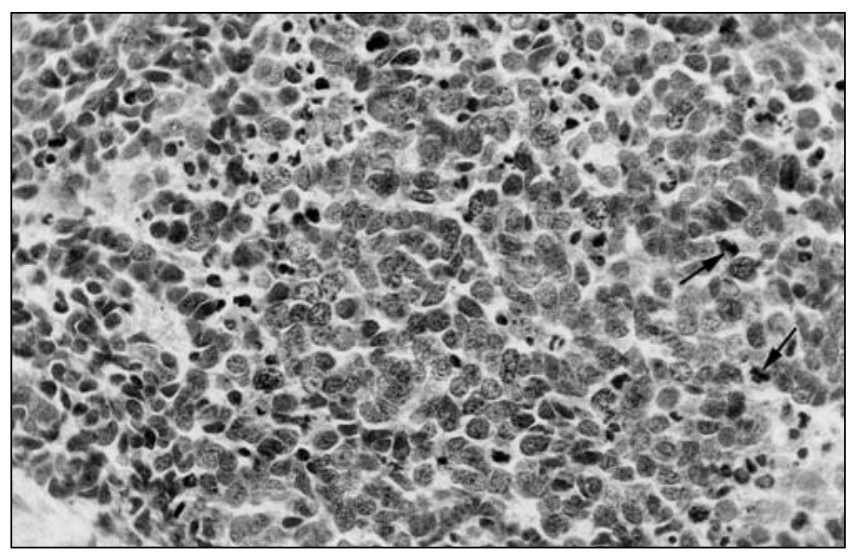

Figure 3) Close up showing small neoplastic cells with dense nuclear chromatin and indistinct cytoplasm. Many mitoses (arrows) including abnormal forms (hematoxylin and eosin stain, original magnification $\times 75$ )

most recent follow-up, ranging from six to 36 months, and one patient had wide local excision with local and regional lymph node radiotherapy and remained disease free at 36 months' follow-up.

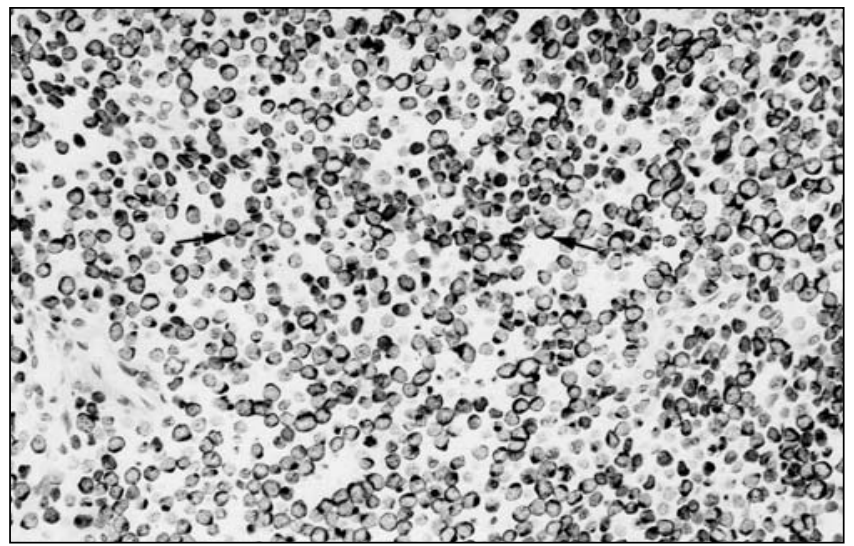

Figure 4) Immunohistochemistry with AE1/AE3 antibody. Characteristic dot-like perinuclear staining (arrows) corresponding to the intermediate keratin filaments (immunoperoxidase stain, original magnification $\times 75$ )

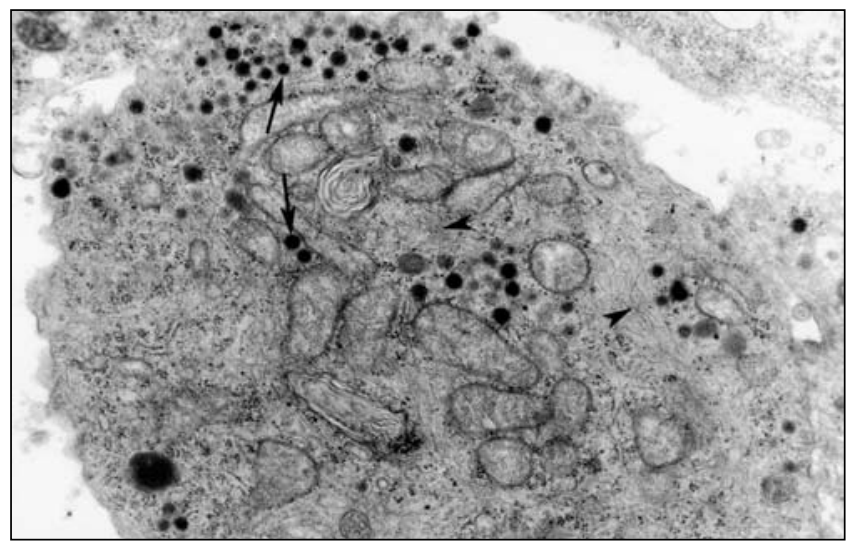

Figure 5) Electron microscopy. Ultrastructurally, cytoplasmic dense core, membrane-bound granules are noted within the cytoplasm (long arrow). Intermediate filaments (short arrow) (electron microscopy, original magnification $\times 8500$ )

One patient was treated initially with radiotherapy only and remained disease free to the most recent follow-up, 36 months after treatment.

When analyzing the recurrence rates with respect to the location of the tumour, four of seven $(57.1 \%)$ patients with head and neck tumours had recurrences. One of four (25\%) patients with extremity lesions had recurrences.

Of the two patients with trunk tumours, one (50\%) had recurrence, and the single patient who presented with stage II disease developed distant metastases.

When analyzing recurrence rates at most recent followup with respect to the stage at initial presentation, of the 10 patients with stage Ia disease, five patients $(50 \%)$ had recurrence, four patients $(40 \%)$ were recurrence free, with a mean time of 26 months, and one patient was lost to followup. Of the three patients with stage Ib disease, one patient $(33.3 \%)$ had recurrence, one patient $(33.3 \%)$ was recurrence free, with mean time of 36 months, and one patient (33.3\%) died of other causes. The single patient who presented with stage II disease developed distant metastases and died 10 months after initial treatment. 
The probability of recurrence-free survival was evaluated using the Kaplan-Meier method (14). Results are shown in Figure 6. Sixty-nine per cent of patients were disease free at the six-month period (no recurrence) and 50\% were disease free at 12 months.

Seven patients had a history that was significant for previous skin disease or other malignancies. Two patients had Bowen's disease (one of whom had Bowen's disease in the location where MCC developed), five patients had basal cell carcinoma, one had squamous cell carcinoma and one had solar keratosis. In addition, one patient had incidental chronic lymphocytic leukemia.

\section{DISCUSSION}

In this study of 14 cases of MCC, immunohistochemistry was required to confirm the diagnosis in seven of 14 patients (50\% of cases) showing a diagnostically helpful pattern for cytokeratin. In all cases tested, a panel of antibodies was required to confirm the neuroendocrine features and to differentiate them from other 'small cell' malignant neoplasms, conforming to other case series in the literature (15).

The disease was distributed equally between men and women, similar to other studies (4). The mean age at diagnosis in our study was 77.7 years, and present data have documented the age range to be from 15 to 97 years, with a mean age of 67.9 years (4).

In this series, the primary tumour was most commonly found in the head and neck, followed by the extremities and the trunk, which is similar to what was found in the literature $(5,8)$.

The anatomical site of the tumour influenced the patients' outcomes. In the present study, patients with extremity lesions had a $25 \%$ recurrence rate, while those with lesions of the head and neck had recurrence rates of $57.1 \%$, with $50 \%$ of those developing distant metastases. Tai et al (8), in an overview of the literature that accounted for 661 patients, found that extremity lesions had the best prognosis and may be related to early detection and wide excisional margin (8). Our patients with extremity lesions were associated similarly with longer disease-free intervals at their most recent follow-up. Duration of disease before presentation for treatment was a significant prognostic factor in our study, because patients who presented later, with lesions at 20 months and 36 months, developed distant metastases, with one patient dying of MCC. This is in agreement with other studies that documented a duration of more than three months at presentation as a poor prognostic factor (8).

Sex was not a significant predictor of survival in our study. Previous studies have documented men to have a worse prognosis than women, independent of the stage and the extent of therapy. Most current data indicate a sex difference for the three-year overall survival of $35.6 \%$ for men and $67.6 \%$ for women $(4,8)$.

No significant differences between stage $\mathrm{Ia}$ and $\mathrm{Ib}$ regarding recurrence rates were evident in our study. Stage Ia disease had a recurrence rate of $50 \%$ and stage $\mathrm{Ib}$ disease

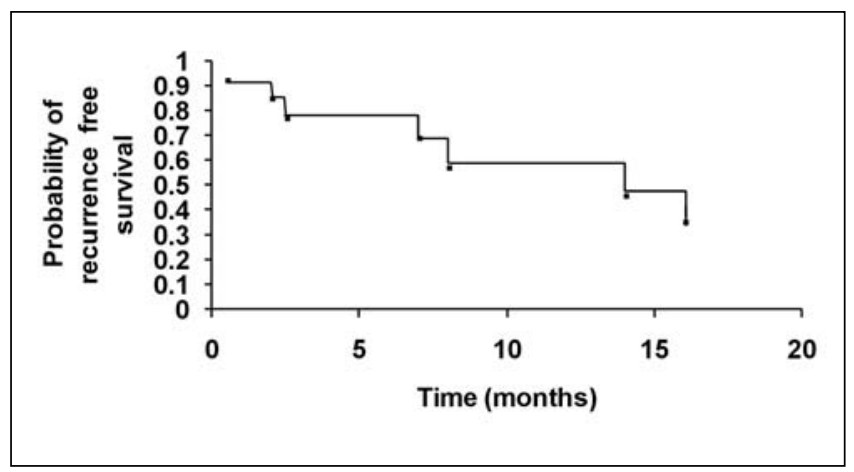

Figure 6) Analysis of recurrence-free survival using Kaplan-Meier method

had a recurrence rate of $33 \%$. Two patients who initially had stage Ia tumours eventually developed distant metastases. The only patient who presented with stage II tumours developed distant metastases and was dead within 10 months of initial treatment. Tai et al (8), in a recent study, found a statistical difference between stage Ia and $\mathrm{Ib}$ tumours. Larger tumour size was associated with lower survival rate, and patients with nodal disease at initial presentation had a worse outcome. There is some controversy regarding this issue, however, as other studies have shown that patients with smaller tumours (primary tumours of less than $2 \mathrm{~cm}$ ) have higher death rates than those with tumours larger than $2 \mathrm{~cm}$ (16).

Our study showed that seven patients had previous skin disease, malignancy and/or immunosuppression. Chronic irritations and inflammation caused by other skin conditions may render an area susceptible to the development of MCC (13). Conditions such as psoriasis and Bowen's disease have been reported to be present at the ultimate site of MCC (13). Our study included one patient who presented with Bowen's disease of the left forehead eight years before the development of MCC at the same location. Chronic inflammation is one of the predisposing factors of other cutaneous malignancies; however, the overall number of cases in this study was too limited to draw conclusions. MCC has been documented to occur in patients with other forms of skin cancer or systemic immunosuppression with a higher frequency than in nonimmunocompromised patients (4). Diseases associated with exposure to ultraviolet radiation also seem to be associated with the development of MCC (13). There appears to be a higher prevalence of MCC in regions with a high incidence of skin cancer (11). The higher occurrence of MCC in sun exposed regions such as the head, neck and extremities is also in keeping with this observation.

Current treatment modalities of MCC include surgery and radiotherapy, but the optimal form and extent of treatment are controversial. Local recurrences arise primarily from inadequate resection of the primary tumour $(4,16)$. Early, complete removal of the tumour may lead to a higher percentage of cure (17). Based on studies that showed significant reduction in local recurrence rate, increasing the 
size of margins from $1 \mathrm{~cm}$ to $3 \mathrm{~cm}$ has been advocated (4). In our study, the highest recurrence rates were in the head and neck regions, possibly due to smaller excision margins.

Several studies have argued that adjuvant locoregional radiotherapy is also required to reduce the incidence of local recurrence $(4,18)$. In our study, the highest recurrence rates occurred in patients who had local excision only as the initial form of treatment. However, patients who had initial wide excision with local radiation and the patient who had initial local wide excision with radiation to local and regional lymph node remained disease free for longer periods. Adjuvant radiotherapy to the primary site showed the best disease-free survival rates in our study. This form of treatment has also been shown in other studies to reduce the incidence of local recurrence $(16,18)$.

In a study by Ott and Tanabe (16), radiotherapy as the only therapy for MCC had a curative role. Four patients in Ott's study were treated primarily with radiotherapy and were disease free for eight, 33, 60 and 92 months, respectively. In our study, the patient who received local radiation only as primary treatment remained free of disease for 36 months after treatment at time of study. In anatomical locations where wide margins cannot be obtained, such as the head and neck, adjuvant radiotherapy has also been documented to be useful in local control, with long term survival rates (16). Our patient who had initial excision only and received local radiation to a recurrence site remained dis-

\section{REFERENCES}

1. Merkel F. Tastzellen und taskorperchen bei den hausthieren und beim menschen. Arch Mikrosc Anal 1875;11:636.

2. Toker C. Trabecular carcinoma of the skin. Arch Dermato 1972;105:107-10

3. Tang CK, Toker C. Trabecular carcinoma of the skin: An ultrastructural study. Cancer 1978;42:2311.

4. Gollard R, Weber R, Kosty W. Merkel cell carcinoma: Review of 22 cases with surgical, pathologic and therapeutic considerations. Cancer 2000;88:1842-50

5. Haag Ml, Glass LF, Fenske NA. Merkel cell carcinoma: Diagnosis and treatment. Dermatol Surg 1995;21:669-83.

6. Freidman RJ, Rigel DS, Kopf AW, Harris MN, Baker D. Cancer of the Skin. Philadelphia: WB Saunders, 1991.

7. Shaw JHF, Rumball E. Merkel cell tumor: Clinical behaviour and treatment. Br J Surg 1991;78:138-42.

8. Tai P, Yu E, Tonita J, Gilchrist J. Merkel cell carcinoma of the skin. J Cutan Med Surg 2000;44:186-95.

9. Ratner D, Nelson BR, Brown MD, Johnson TM. Merkel cell carcinoma. J Am Acad Dermatol 1993;29:143-56.

10. Chan JK, Suster S, Wenig BM, Tsang WY, Chan JB, Lau AL. Cytokeratin 20 immunoactivity distinguishes Merkel cell (primary cutaneous neuroendocrine) carcinoma and salivary gland small cell carcinoma from small cell carcinoma of various sites. Am J Surg ease free for 36 months at the most recent follow-up. Studies have documented radiation to be effective in any part of the treatment course, regardless of whether it was given initially or to recurrent sites (8).

\section{CONCLUSION}

The present review indicates that MCC behaves as an aggressive tumour. MCC occurs most frequently in the head and neck of elderly white people, with equal incidence between men and women. The histological diagnosis of MCC may require a panel of immunohistochemical markers for confirmation. High local recurrence rates suggest that an adequate margin of clearance of up to $3 \mathrm{~cm}$ is necessary, similar to most recent studies. Adjuvant radiation following surgical excision had best results for disease-free intervals. Radiation to regions where larger excisional margins are not feasible may lengthen disease-free survival. Radiotherapy plays an important role in the treatment of $\mathrm{MCC}$ in any course of therapy. Although optimal management of MCC has not been established, combination treatment advocating wide surgical excision with adjuvant radiotherapy provides a response rate that increases diseasefree periods and overall survival.

ACKNOWLEDGEMENTS: The authors thank Karen Veltri, $\mathrm{MSc}$, for her assistance in the preparation of this manuscript.

Pathol 1997;21:226.

11. Redmond J III, Perry J, Sowray P, Vukelja SJ, Dawson N. Chemotherapy of disseminated merkel cell carcinoma. Am J Clin Oncol 1991;14:305-7.

12. Fenig E, Lurie H, Klein B, Sulkes A. The treatment of advanced merkel cell carcinoma. A multimodality chemotherapy and radiation approach. J Dermatol Surg Oncol 1993;19:860-4.

13. Pitale M, Sessions RB, Husain S. An analysis of prognostic factors in cutaneous neuroendocrine carcinoma. Laryngoscope 1992;102:244-9.

14. Kaplan EI, Meier P. Nonparametric estimation from incomplete observations. J Am Stat Assoc 1958;53:457-81.

15. Visscher D, Cooper P, Zarbo R, Crissman J. Cutaneous neuroendocrine (Merkel cell) carcinoma: An immunopheotypic, clinicopathologic and flow cytometric study. Modern Pathol 1989;2:331-8.

16. Ott M, Tanabe K. Multimodality management of Merkel cell carcinoma. Arch Surg 1999;134:388-93.

17. Hanke CW, Conner AC, Temofew RK, Lingeman RE. Merkel cell carcinoma. Arch Dermatol 1989;125:1096-100.

18. Boyle F, Pendlebury S, Bell D. Further insights into the natural history and management of primary cutaneous neuroendocrine (Merkel cell) carcinoma. Int J Radiat Oncol Biol Phys $1995 ; 31: 315-22$. 
In the paper "Clinical-pathological review of 14 cases of merkel cell carcinoma" by Quttainah et al (Can J Plast Surg 2002;10(5):196-202), the French abstract was printed incorrectly. The abstract, as it should have appeared, is printed below. Our apologies are extended to the authors.

A Quttainah, A Thoma, S Salama. Clinical-pathological review of 14 cases of merkel cell carcinoma. Can J Plast Surg 2002;10(5):196-202.

Merkel cell carcinoma (MCC) is a rare, primary, cutaneous, neuroendocrine skin tumour that occurs commonly in the head, neck or extremities of elderly white people. Fourteen cases of MCC in the Hamilton Regional Cancer Centre between 1992 and 2000 have been reviewed. Seven cases required a panel of immunohistochemical markers and two cases required electron microscopy for confirmation. Seven men and seven women were treated, and ranged from 67 to 96 years of age (mean 77.7 years). The primary tumour was located in the head and neck in seven patients $(50 \%)$, in the extremities in four patients $(29 \%)$ and on the trunk in two patients (14\%). One patient had an unknown primary tumour location. Ten patients had stage Ia disease at presentation, three had stage $\mathrm{Ib}$ disease, and one presented with stage II disease. Primary treatment consisted of wide local excision in nine patients, wide local excision and radiotherapy in four patients and radiotherapy only in one patient. Seven patients had recurrence, five were disease free up to their most recent followup, one died of unrelated causes, and one was lost to follow-up after primary treatment. Of the seven patients with recurrence, two had local recurrence, two had lymph node recurrence and three developed metastases. Disease-free intervals were 69\% and $50 \%$ for six-month and one-year follow-up, respectively. No difference in outcome was observed between stage Ia and Ib disease. The patient with stage II disease at presentation developed metastases. Longer duration of disease before presentation had a higher incidence of recurrence with distant metastases. Extremity lesions had the best prognosis associated with disease-free interval. Early management with excision and radiotherapy improved the disease-free interval.

Key Words: Merkel cell carcinoma; Neuroendocrine tumour, Trabecular cell carcinoma

\section{Un examen clinicopathologique de 14 cas de carcinome à mélanoblaste}

Le carcinome à mélanoblaste (CM) est une tumeur cutanée neuroendocrinienne rare et primaire qui se manifeste souvent sur la tête, le cou ou les extrémités de personnes âgées blanches. Quatorze cas de CM observés au Hamilton Regional Cancer Centre entre 1992 et 2002 ont été analysés. Sept cas ont exigé un groupe de marqueurs immunohistochimiques et deux cas, une confirmation par microscopie électronique. Sept hommes et sept femmes, de 67 à 96 ans (âge moyen de 77,7 ans), ont été traités. La tumeur primaire se situait sur la tête et le cou chez sept patients (50\%), aux extrémités chez quatre patients $(29 \%)$ et sur le tronc chez deux patients $(14 \%)$. Le foyer de la tumeur primaire d'un patient était inconnu. Dix patients présentaient une maladie de stade Ia, trois, une maladie de stade Ib et un, une maladie de stade II. Le traitement primaire s'est traduit par une large excision locale chez neuf patients, une large excision locale accompagnée d'une radiothérapie chez quatre patients et une radiothérapie seule chez un patient. Sept patients ont souffert de récurrences et cinq ne présentaient plus la maladie à leur plus récent suivi, un est décédé de causes non apparentées et un a été perdu de vue après le traitement primaire. Des sept patients ayant souffert de récurrence, deux ont présenté une récurrence locale, deux ont présenté une récurrence dans les ganglions lymphatiques et trois ont développé des métastases. Les intervalles sans maladie s'établissaient à $69 \%$ et à $50 \%$ au suivi de six mois et de un an, respectivement. Aucune différence d'issue ne s'observait entre la maladie de stade Ia et de stade Ib. Le patient atteint d'une maladie de stade II à la présentation a développé des métastases. Une maladie plus longue avant la présentation s'associait à une incidence plus élevée de récurrence avec métastases distantes. Les lésions aux extrémités s'accompagnaient du meilleur pronostic d'intervalle sans maladie. Une prise en charge précoce par excision et radiothérapie accroissait l'intervalle sans maladie. 